\title{
Precambrian non-marine stromatolites in alluvial fan deposits, the Copper Harbor Conglomerate, upper Michigan
}

\author{
R. DOUGLAS ELMORE* \\ Department of Geological Sciences, The University of Michigan, \\ Ann Arbor, MI 48109, U.S.A.
}

\begin{abstract}
A BSTRACT
Laminated cryptalgal carbonates occur in the Precambrian Copper Harbor Conglomerate of northern Michigan, which was deposited in the Keweenawan Trough, an aborted proto-oceanic rift. This unit is composed of three major facies deposited by braided streams on a large alluvial-fan complex. Coarse clastics were deposited in braided channels, predominantly as longitudinal bars, whereas cross-bedded sandstones were deposited by migrating dunes or linguoid bars. Fine-grained overbank deposits accumulated in abandoned channels. Gypsum moulds and carbonate-filled cracks suggest an arid climate during deposition.

Stromatolites interstratified with these clastic facies occur as laterally linked drapes over cobbles, as laterally linked contorted beds in mudstone, as oncolites, and as poorly developed mats in coarse sandstones. Stromatolites also are interbedded with oolitic beds and intraclastic conglomerates. Stromatolitic microstructure consists of alternating detrital and carbonate laminae, and open-space structures. Radialfibrous calcite fans are superimposed on the laminae. The laminae are interpreted as algal in origin, whereas the origin of the radial fibrous calcite is problematic.

The stromatolites are inferred to have grown in lakes which occupied abandoned channels on the fan surface. Standing water on a permeable alluvial fan in an arid climate requires a high water table maintained by high precipitation, or local elevation of the water table, possibly due to the close proximity of a lake. Occurrence of stromatolites in the upper part of the Copper Harbor Conglomerate near the base of the lacustrine Nonesuch Shale suggests that these depositional sites may have been near the Nonesuch Lake.
\end{abstract}

\section{INTRODUCTION}

Carbonate deposits interpreted as cryptalgal (Aitken, 1967) have been described from a number of ancient non-marine units (Bradley, 1929; Belt, 1966; Fannin, 1969; Button, 1973; Hoffman, 1976; Clemmensen, 1978; Riding, 1979; Krylov, 1982). Many of these are associated with features indicating fluctuating water levels due to periodic desiccation in lakes (Surdam \& Wray, 1976; Link, Osborn \& Awramik, 1978; Abell et al., 1982). Less commonly, stromatolites have been

* Present address: School of Geology and Geophysics, The University of Oklahoma, Norman, OK 73019, U.S.A.

0037-0746/83/1200-0829\$02.00

(C) 1983 International Association of Sedimentologists reported from palaeostream channels (Link et al., 1978; Abell et al., 1982). Recognition and interpretation of such carbonates can provide valuable information on the limnology, climatology, and sedimentology of ancient non-marine systems which may not be available from the associated rocks. For example, stromatolites in Pliocene non-marine deposits from California are thought to indicate periods of tectonic quiescence and/or low rates of clastic sedimentation (Link et al., 1978), whereas stromatolites in the Green River Formation of Wyoming and Utah have been used to quantify fluctuations in shoreline position of Eocene Lake Gosuite (Surdam \& Wray, 1976).

The purpose of this paper is to describe laminated 
cryptalgal carbonates in coarse-grained alluvial fan deposits of the Keweenawan Copper Harbor Conglomerate of upper Michigan. Occurrence of these stromatolite beds and associated oolite-oncolite beds in braided stream deposits of an alluvial fan appears incongruous, and yet provides valuable palaeoenvironmental information. The stromatolites also are of interest because some of the fabrics they contain are enigmatic when compared with modern carbonates.

\section{GENERAL SETTING}

The Copper Harbor Conglomerate was deposited in the ensialic Keweenawan Trough, an intracontinental rift filled with a thick succession of volcanics and clastics (Fowler \& Kuenzi, 1978). Part of this sequence is well exposed on the Keweenaw Peninsula of northern Michigan, beginning with mafic volcanics and subordinate clastics of the Portage Lake Lava

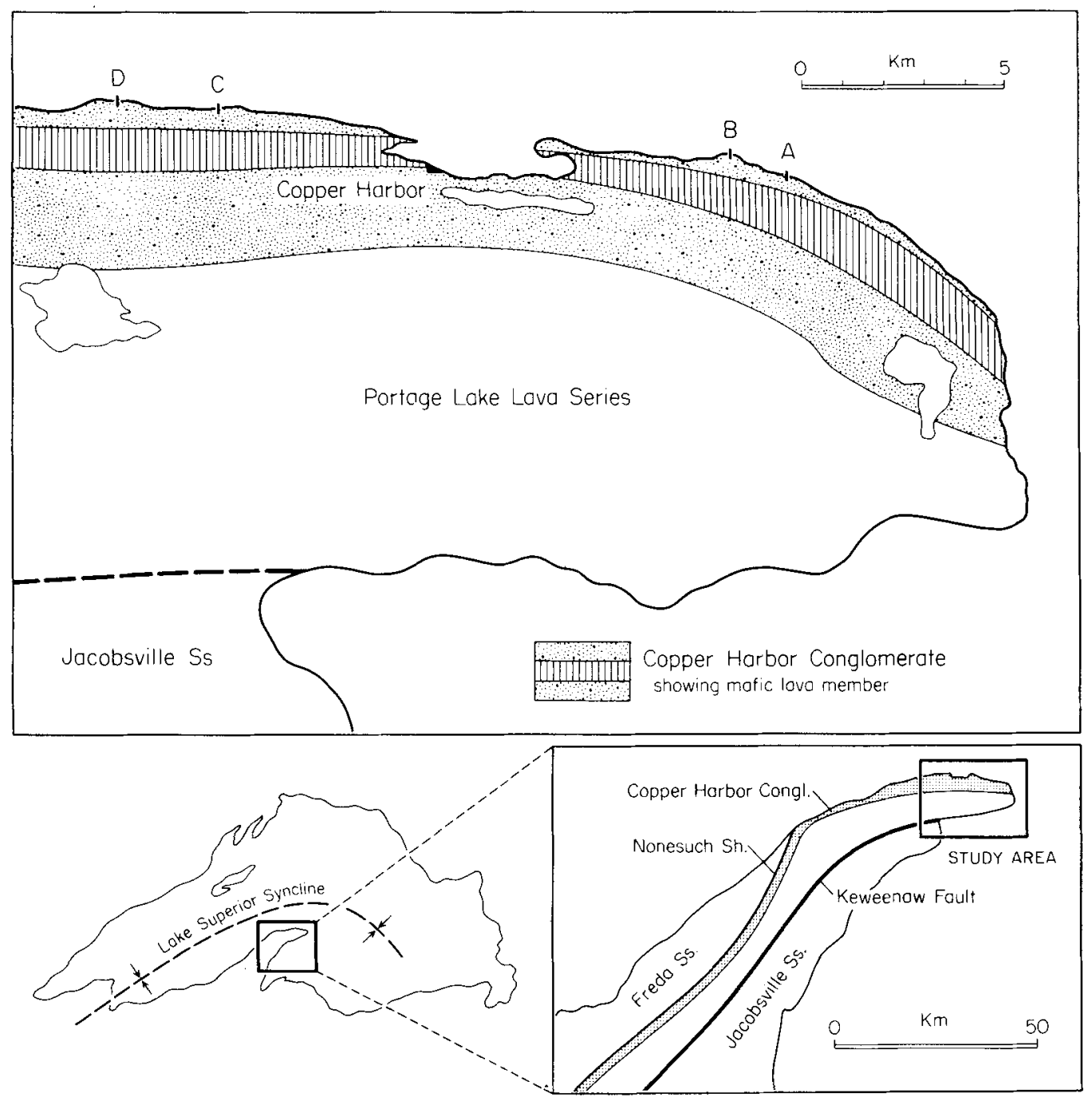

Fig. 1. Simplified geological map of the north-eastern part of the Keweenaw Peninsula of northern Michigan, with index maps showing the distribution of major rock types on the Keweenaw Peninsula and location of the study area. Stromatolite localities indicated by letters A, B, C, D. Modified from Cornwall $(1954,1955)$. 
Series (White, 1968). This unit is overlain by the Copper Harbor Conglomerate which is in turn overlain by the Nonesuch Shale and Freda Sandstone (Fig. 1). Palaeomagnetic measurements suggest that the sequence was deposited at low latitudes (Henry, Mauk \& Van der Voo, 1977).

The Copper Harbor Conglomerate is a finingupward, basinward-thickening wedge of red conglomerate and sandstone with subordinate volcanics that has been interpreted as a piedmont fan deposit (White $\&$ Wright, 1960). Most of the clasts are felsic volcanics which were transported toward the basin centre, whereas the mafic volcanics in the Portage Lake Lava Series and the base of the Copper Harbor Conglomerate flowed away from the axis of the basin (White \& Wright, 1960). The conglomerates probably represent periods of time when extrusion of lava did not keep pace with downwarping of the basin (White, 1960). The Copper Harbor Conglomerate, and the overlying Nonesuch Shale and Freda Sandstone, are interpreted as a transgressive-regressive clastic sequence that filled the rift basin during and after the cessation of volcanic activity (Fig. 2).

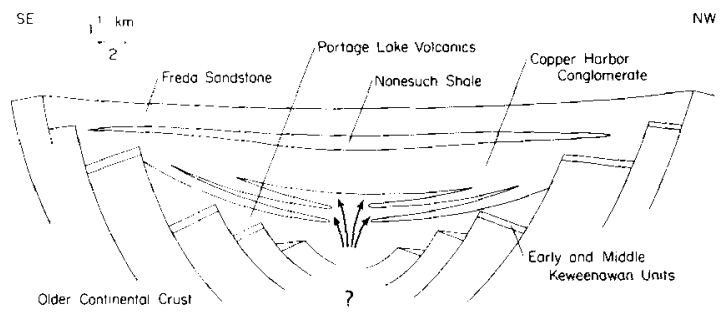

Fig. 2. Tectonic model for the Keweenawan Trough during deposition of the Freda Sandstone. Cross-section is schematic and could represent any section across the basin. Modified from Fowler \& Kuenzi (1978).

The stromatolites, which occur in the upper half of the Copper Harbor Conglomerate, are exposed at a number of localities on the shore of Lake Superior along the north-eastern part of the Keweenaw Peninsula (Fig. 1) and have been generally described by Hedlund (1953), Nordeng (1963) and Cornwall (1955). Similar limestone deposits have been reported from the Solar Church Formation (Morey, 1974), a Keweenawan deposit similar to the Copper Harbor Conglomerate in the subsurface of Minnesota.

\section{FACIES DESCRIPTION}

Sections measured at all stromatolite localities allow for the definition of three major clastic facies associated with the stromatolitic limestones (Fig. 3).

\section{Conglomerate}

This is the most abundant facies and consists of poorly sorted cobble-to-boulder gravel conglomerate beds exhibiting crude horizontal stratification, interbedded with thin lenticular sandstone (Figs 3,4A). Individual conglomerate beds range up to $1 \mathrm{~m}$ in thickness, and are commonly superimposed, forming 5-20 m-thick units which are laterally continuous for hundreds of metres. Most individual beds, however, are discontinuous, but exhibit little channeling. Some beds fine upward from cobble to pebble conglomerate. Pebbles within these clast-supported conglomerates are imbricated (Fig. 3), with the $A B$ planes dipping to the south, indicating that the currents were flowing to the north (cf. Walker, 1975), that is, into the basin. Sandstone interbeds, usually between 10 and $50 \mathrm{~cm}$ thick, generally have gradational bottoms with underlying gravels and sharp erosional tops. They contain ripple, trough, and horizontal stratification, and a few mud drapes. In addition, rare, clast-supported cobbleto-pebble gravel occurs in shaliow troughs less than $1 \mathrm{~m}$ thick.

This facies is similar to coarse alluvium in modern braided streams (Boothroyd \& Ashley, 1975) and to ancient braided stream deposits (Miall, 1977, 1978). The crude horizontal stratification, imbrication and intercalated sandstones in these conglomerates suggest deposition by fluvial processes on longitudinal bars (Miall, 1977). The interbedded sandstones either filled channel scours or resulted from migration of bedforms over the bars during periods of low flow (Miall, 1977). The cross-stratified gravel represents fill in minor channels or lateral accretion on longitudinal bars (Miall, 1977; Rust, 1979).

\section{Trough cross-stratified sandstone}

This facies is predominantly composed of trough cross-stratified sandstone in multiple sets a few to tens of metres thick (Fig. 4B). Individual troughs are typically $30-50 \mathrm{~cm}$ thick and have widths of up to $4 \mathrm{~m}$ and lengths of up to $6 \mathrm{~m}$. Grain size is usually mediumto-coarse sand, commonly with pebble-to-cobble stringers as well as isolated conglomerate clasts. Both wave and current ripples, as well as horizontally stratified sandstone with parting lineation and, rarely, planar-tabular cross-stratified sandstones are also present in this facies. Some of these features occur in sequences $2-5 \mathrm{~cm}$ thick composed of laminated sandstone overlain by rippled sandstone (Fig. 4C), which in turn is covered by a mudcracked mud drape. Palaeocurrent directions, determined from the axes of 


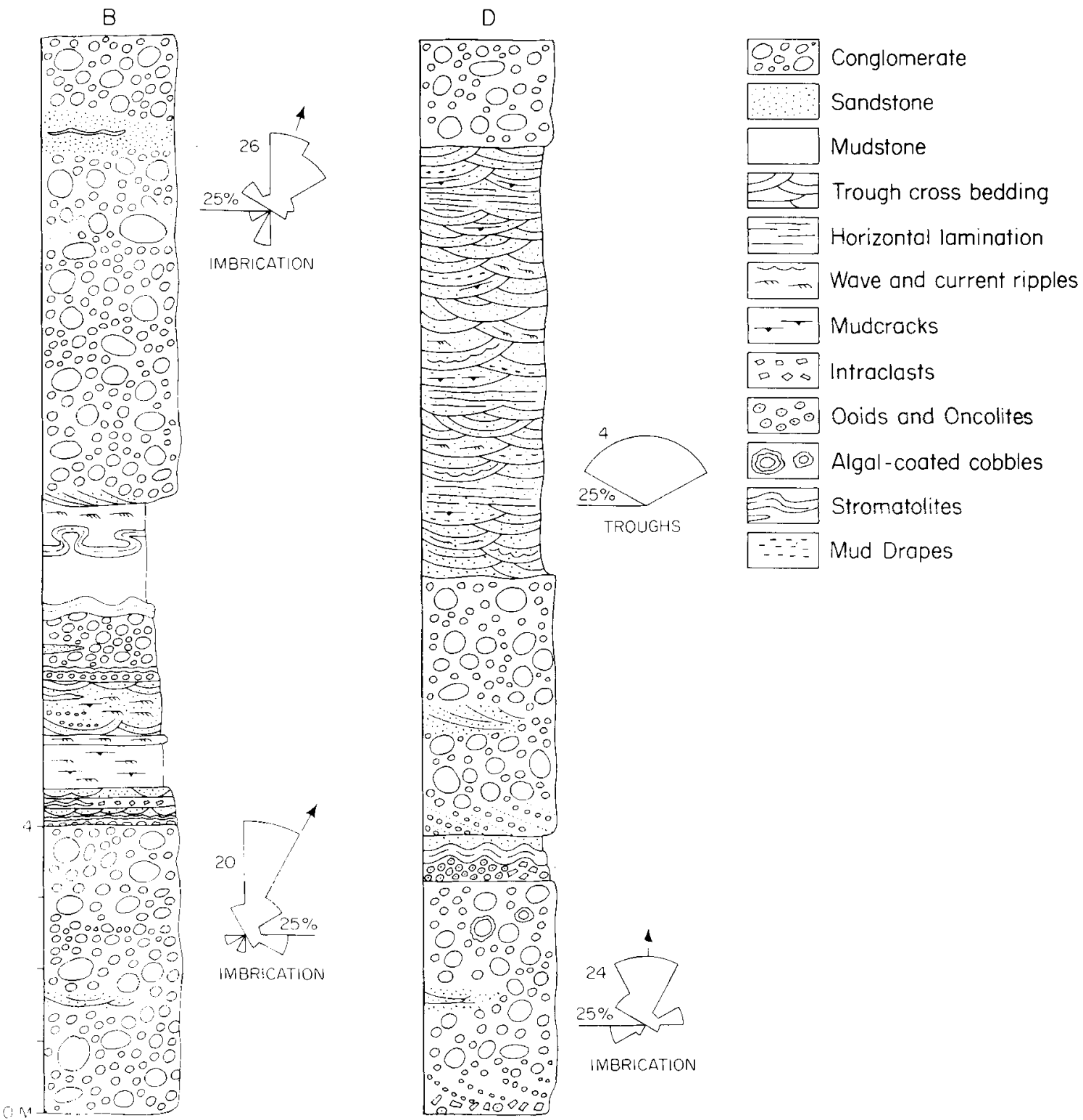

Fig. 3. Measured sections from Horseshoe Bay (B) and Dan's Point (D), with current-direction rose diagrams. Section B shows the conglomerate-mudstone facies bounded above and below by the conglomerate facies. Section $\mathrm{D}$ illustrates the conglomerate and trough cross-stratified sandstone facies.

troughs and ripple crests, indicate that sediment was transported northward into the basin (Fig. 3), in agreement with the results of other workers (White \& Wright, 1960; Hamblin \& Horner, 1961).

The evidence of desiccation, stratification types and generally unimodal palaeocurrent patterns suggests deposition by alluvial processes. This facies is also similar to the deposits of braided streams (Boothroyd \& Ashley, 1975; Miall, 1977). The trough cross-stratified sandstone facies records the migration of dunes and/or linguoid bars in channels. The thin sequences with mudcracked mud drapes are interpreted as waning flow sequences of individual flood events. The current ripples migrated across bars 

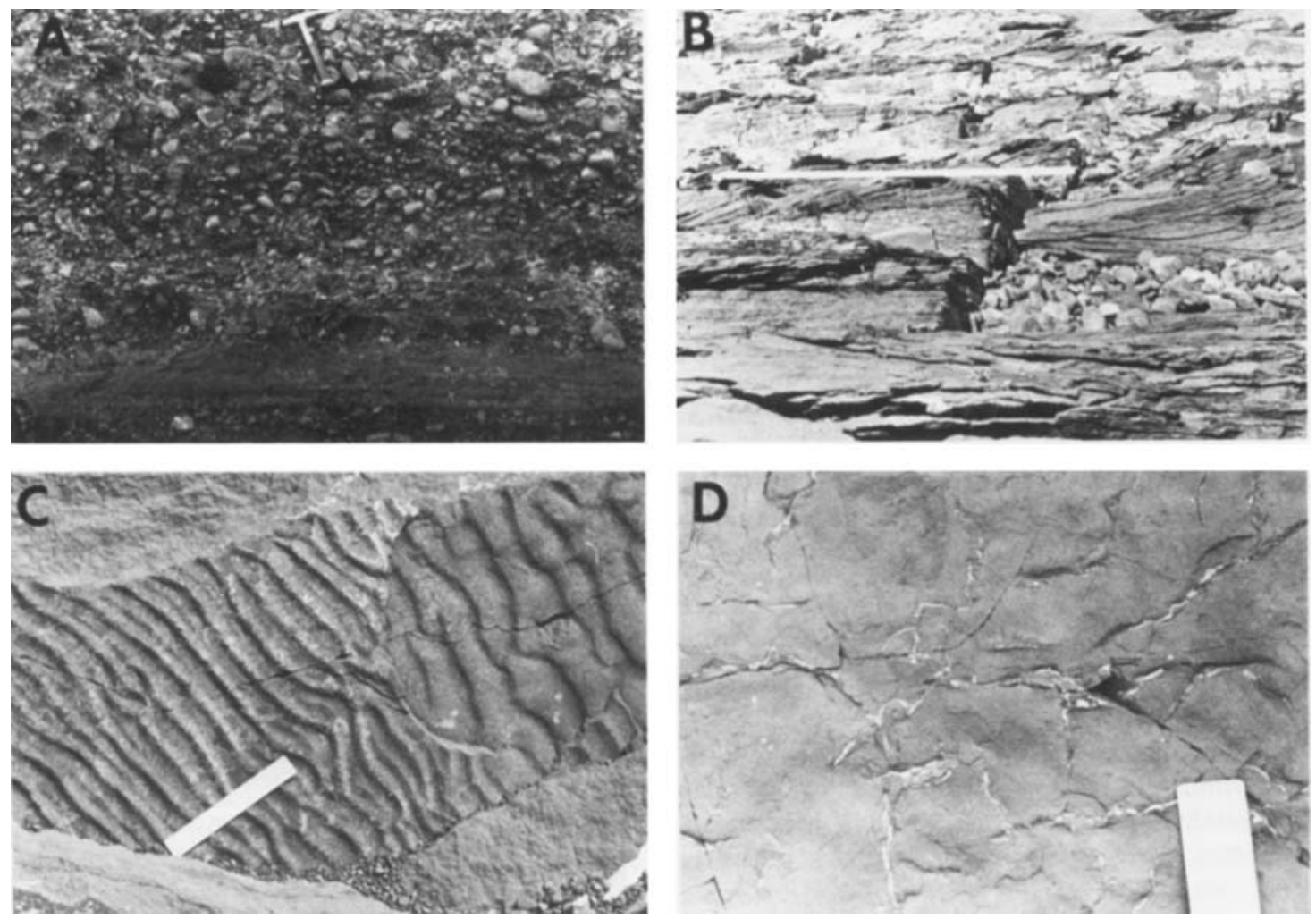

Fig. 4. Photographs of the clastic facies. (A) Conglomerate facies with interstratified lenticular sandstone. (B) Trough crossstratified sandstone facies. Jacob's staff is $1.5 \mathrm{~m}$ long. (C) Ripples in the trough cross-stratified sandstone facies. Ruler is $15 \mathrm{~cm}$ long. (D) Incomplete cracks, filled with calcite, from the conglomerate-mudstone facies.

during low flow and the wave ripples formed in shallow standing water. The mud drapes resulted from settle out of fine material in ponded water or from percolation of water into the porous sands. The abundance of these waning flow sequences, and particularly the mud drapes which are characteristic of modern ephemeral channels (Glennie, 1970; Karcz, 1972), may indicate that the Copper Harbor Conglomerate was deposited by such streams. During the Precambrian, however, rivers in humid climates were probably 'flashy' because there were no land plants (Schumm, 1977), and would have had hydrologic regimes similar to modern arid ephemeral rivers. As a result, deposits of Precambrian humid and modern arid rivers might be similar, making interpretation of climate difficult.

\section{Conglomerate-mudstone}

This facies is a complex association of various lithologies ranging from conglomerate to mudstone
(Fig. 3). Because individual units are often impersistent and less than $25 \mathrm{~cm}$ thick, the association is best considered as one facies rather than a complex set of separate lithofacies. Discrete units within this facies include thin $(<30 \mathrm{~cm})$ pebble-to-cobble conglomerates, trough cross-stratified sandstone, ripple crossstratified sandstone, horizontally stratified sandstone with parting lineation, mud chip conglomerate, laminated siltstone, and mudstone. Mud drapes, mudcracks, and rain drop imprints, as well as polygonal to irregular shrinkage cracks filled with 5 $10 \mu \mathrm{m}$ calcite are also present (Fig. 4D). As with the trough cross-stratified sandstone facies, palaeocurrent directions indicate that currents were flowing to the north or into the basin centre (Fig. 3).

The units in this facies occur in 4-7 $\mathrm{m}$ associations which in places exhibit a general fining-upward trend (Fig. 3, section B). These associations are interpreted as resulting from the gradual abandonment of channels in a braided river. After initial abandonment, silts 
and sands were deposited as a result of overbank deposition. During infrequent occupation, probably during flood events, pebble-to-cobble conglomerate was deposited in sheets on ripples or on longitudinal bars, while sand was deposited by migrating dunes. This cycle was repeated a number of times until the area was finally re-occupied, resulting in deposition of coarse conglomerate. The cracks with a polygonal pattern are probably desiccation cracks. The interpretation of the irregular cracks is not as straightforward. They are similar to subaqueous shrinkage or syneresis cracks (Donovan \& Foster, 1972) and to incomplete subaerial desiccation cracks (Plummer \& Gostin, 1981). They could be desiccation or syneresis cracks; there is considerable overlap in morphology between the two types which can make differentiation difficult (Plummer \& Gostin, 1981).

\section{STROMATOLITES AND ASSOCIATED LIMESTONES}

Stromatolites in the Copper Harbor Conglomerate are most commonly associated with the conglomeratemudstone facies, although they also occur interbedded with conglomerate facies. They are exposed intermittently along strike for $15 \mathrm{~km}$, occurring at approximately the same stratigraphic position within the Copper Harbor Conglomerate. Some beds, however, are separated by a stratigraphic thickness of $75 \mathrm{~m}$. In addition to being interbedded with clastic units, stromatolites are associated with beds containing ooids, oncolites and intraclasts. Stromatolites occur as bedded laterally linked forms in mudstone, as oncolites, and as poorly developed mats in coarse sandstone. In addition, conglomerate above and below the bedded stromatolite at one locality (Fig. 3, section D) contains numerous stromatolite-coated boulders and cobbles which range in diameter from 8 to $50 \mathrm{~cm}$.

\section{Stromatolite macrostructure}

The most common stromatolite morphology is that of laterally linked hemispheroids developed as drapes over cobbles (Fig. 5A, B). These hemispheroids are continuously linked or spaced and exhibit high inheritance (Hofmann, 1969). Total thicknesses range from 1 to $30 \mathrm{~cm}$, and individual hemispheroids reach a maximum diameter of $40 \mathrm{~cm}$. Most of the hemispheroids are bulbous (Fig. 5C) or somewhat pointed, have a knobby surface, and are composed of coalesced second- and third-order hemispheroids. The smallest
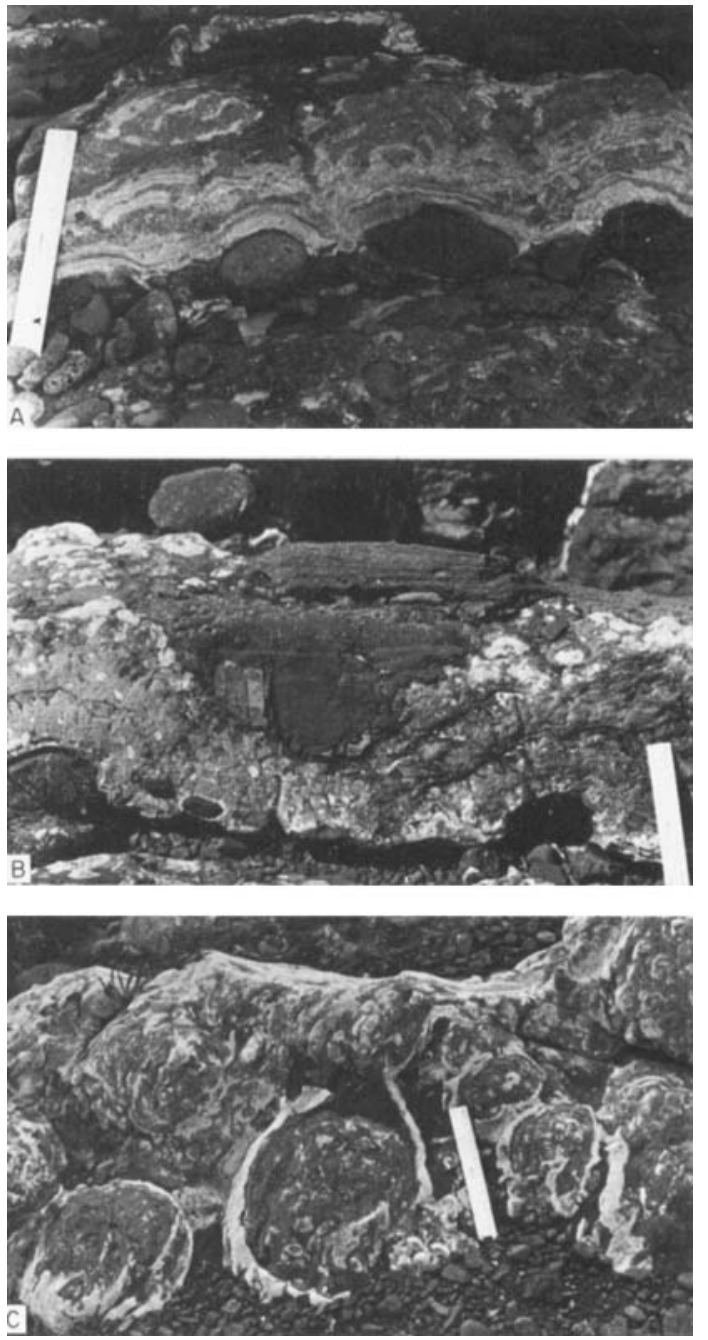

Fig. 5. Photographs of stromatolites. (A) Laterally linked stromatolites draped over cobbles. (B) Pointed stromatolite hemispheroids developed over cobbles. Note fine sand filling areas between the hemispheroids. (C) Top of bulbous stromatolite hemispheroids. Note knobby surface due to coalesced second- and third-order hemispheroids.

hemispheroids (third order) average $1 \mathrm{~cm}$ in width and $3 \mathrm{~cm}$ in height, range from cylindrical to bulbous, and in section exhibit an anastomosed branching pattern (Fig. 6A). Many detrital clasts (up to cobble gravel) are included within the stromatolite laminae and occur in pockets between the higher-order hemispheroids. The stromatolites grade laterally into, and are interbedded with, oolite-oncolite beds and 

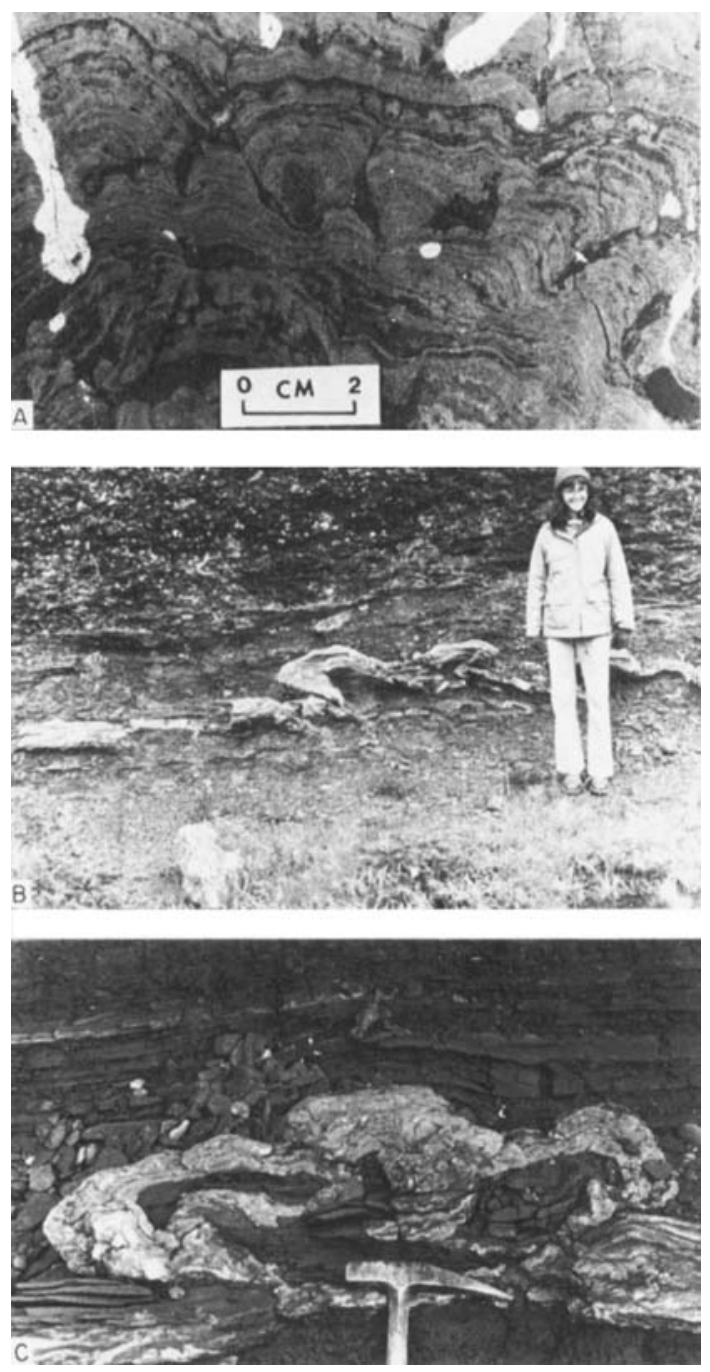

Fig. 6. Photographs of stromatolites. (A) Polished slab of stromatolite illustrating the hemispheroids, which exhibit an anastomosed branching pattern. (B) Undulatory laterally linked stromatolite in mudstone beneath massive conglomerates. (C) Mushroom-shaped stromatolite in mudstone.

intraclastic conglomerate composed of stromatolite chips.

Stromatolites also occur within mudstone as discontinuous lenses and at one locality (Fig. 3, section B) as an undulatory, laterally linked bed which appears to be contorted and folded (Fig. 6B). Large mushroomshaped forms are present at this locality, having a diameter of up to $1.5 \mathrm{~m}$ and a relief of up to $50 \mathrm{~cm}$
(Fig. 6C). These commonly contain shale cores and have overhanging margins. Flat-lying stromatolites which connect the mushroom-shaped forms locally protrude down into the underlying mudstone, indicating some post-depositional deformation.

The origin of contorted stromatolite in this mudstone is problematic. Hedlund (1953) suggested that these features represent slightly deformed original growth forms. However, this does not explain the contorted nature of the beds, which indicates postdepositional deformation. Two possibilities seem plausible. The deformation could have resulted from loading of the soft mudstone during deposition of the overlying conglomerate, or conversely, the deformation could have taken place much later during tectonic deformation of the entire sequence.

\section{Stromatolite microstructure}

The basic microfabric within the stromatolites consists of couplets of light-dark laminae which range from approximately $20 \mu \mathrm{m}$ to a few millimetres in thickness (Fig. 7A). Each lamina is composed of calcite and/or detrital material, with the darker laminae containing greater quantities of fine hematite. All gradations between totally terrigenous laminae and totally carbonate laminae are present. Sand- and silt-sized detrital grains are common in both light and dark laminae, and occur on the inclined sides of hemispheroids.

Filled cavities from tens of micrometres to several millimetres in diameter are irregular in shape, although most are elongate parallel to laminae. Many are filled with coarse calcite, although some are filled with anhedral microspar that is probably neomorphic in origin. These structures are similar to the open space structures of Horodyski (1975) which he interpreted as primary voids, shrinkage voids and/or displacive structures produced by the decay of organic matter. The voids in the Copper Harbor Conglomerate stromatolites may have a similar origin, although some may have formed during late diagenesis or metamorphism of the rocks. Pseudomorphs of calcite after gypsum are present also within some intervals (Fig. 7B).

Superimposed on some of the laminae are radialfibrous calcite fans oriented perpendicular to the laminae (Fig. 7C, D). Continuous layers of radialfibrous calcite range in thickness from 2 to $5 \mathrm{~mm}$ and commonly occur in tiers separated by microspar (Fig. 7D). Individual crystals of radial calcite within 

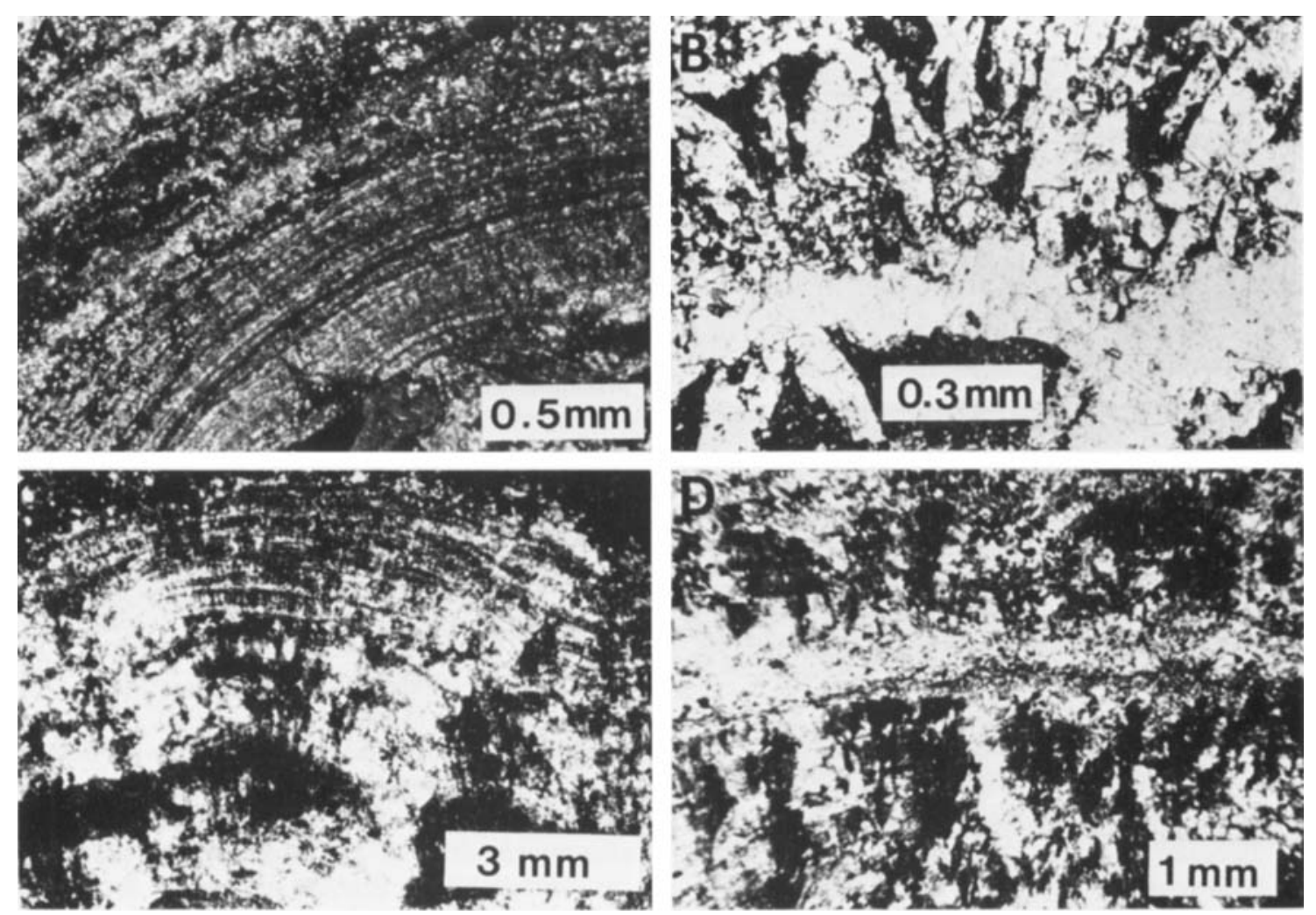

Fig. 7. Photomicrographs of stromatolite microstructures. (A) Stromatolite laminae. Plane-polarized light. (B) Pseudomorphs of calcite after gypsum from within the stromatolite. Plane-polarized light. (C) Radial fibrous calcite fans superimposed on stromatolite laminae. X-polars. (D) Tiers of radial fibrous calcite superimposed on stromatolite laminae. X-polars.

the fans are typically irregular, ranging from equant $(\sim 20 \times 20 \mu \mathrm{m})$ to elongate $(20 \times 80 \mu \mathrm{m})$.

The stromatolites also contain circular, spar-filled structures which have diameters from $100 \mu \mathrm{m}$ to $1 \mathrm{~mm}$. These are similar, although considerably larger than coccoid algae reported from other ancient lacustrine deposits which average $100 \mu \mathrm{m}$ in diameter (Bradley, 1929; Link et al., 1978; Clemmensen, 1978) and, because of their size, may be air bubble cavities.

\section{Associated limestone deposits}

Ooids and oncolites occur interstratified with stromatolites in discrete, grain-supported beds and as individual ooids and oncolites incorporated into stromatolite laminae (Fig. 8A). Oncolite nuclei are composed of compound ooids, intraclasts and detrital clasts.

Ooids range in diameter from 0.4 to $2 \mathrm{~mm}$ and in shape from spheroidal to ellipsoidal (Fig. 8B). Nuclei are variable and include volcanic rock fragments, quartz, feldspar, intraclastic carbonate and fragments of ooid cortices. Compound and broken ooids, as well as asymmetrical ooids, and ooids with multiple and protruding nuclei are present also. Individual laminae within the ooids range from 10 to $100 \mu \mathrm{m}$, with most having a uniform thickness. Many laminae within the ooids are discontinuous, indicating asymmetric growth, and some are crenulated. XRD analyses reveal that ooid cortices are composed of low- $\mathrm{Mg}$ calcite, with minor amounts of hematite in the concentric laminae. Some ooids are partially-to-wholly composed of a chamosite-type mineral, which has apparently replaced the original carbonate.

Unreplaced calcite ooids commonly exhibit welldeveloped laths of low-Mg calcite ranging from large $(100 \times 5-10 \mu \mathrm{m})$ to small $(10-15 \times 2-5 \mu \mathrm{m})$, oriented perpendicular to the nuclei. The larger crystals appear to be gradational with more equant crystals which exhibit a similar extinction pattern. 

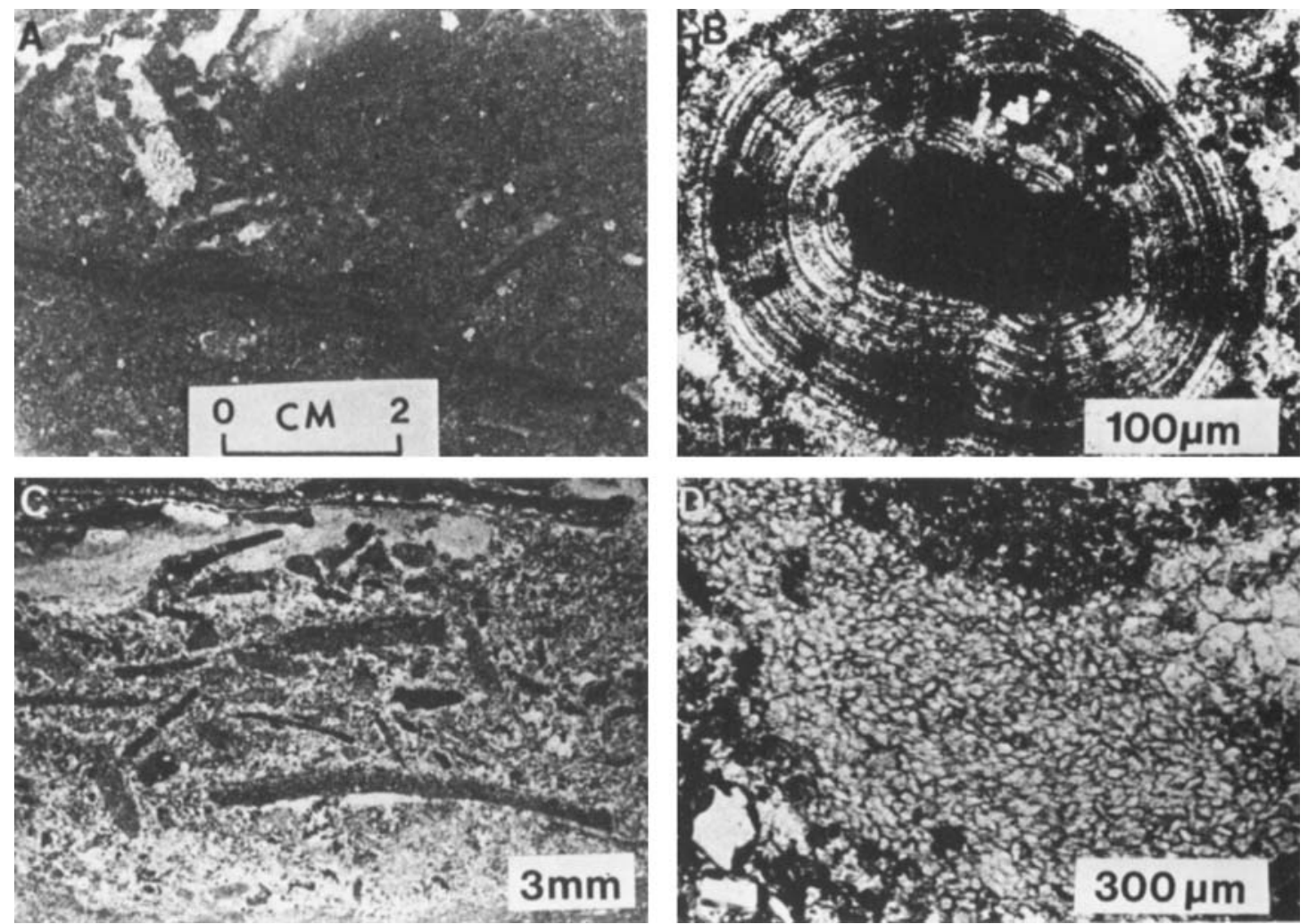

Fig. 8. Examples of the associated limestone deposits. (A) Polished slab of oolite oncolite bed showing oncolites, ooids and compound ooids. (B) Ooid with radial fibrous calcite cortex. X-polars. (C) Intraclastic limestone associated with the stromatolites. Plane-polarized light. (D) Rhomb-shaped grains in an apparently geopetal accumulation. Plane-polarized light.

Lenses of intraclastic limestone, predominantly composed of stromatolite and/or oolite fragments, are interbedded with the stromatolites (Fig. 8C). Voids between the clasts commonly are partially filled with geopetal accumulations of $10 \mu \mathrm{m}$ anhedral calcite, probably recrystallized micrite. Accumulations of wheat-shaped, apparently detrital grains $(15-20 \mu \mathrm{m}$ long and $6-10 \mu \mathrm{m}$ wide) are also present (Fig. 8D). These are similar to rhombs of calcite associated with filaments of blue-green algae in Recent sediments (Monty, 1976), but they are somewhat larger, and their origin is problematic.

\section{DISCUSSION}

Laminated carbonates and associated deposits in the Copper Harbor Conglomerate are of interest for several reasons. Thin beds of similar limestone have been reported from numerous non-marine clastic sequences. A key question when dealing with this type of carbonate is whether the laminae are cryptalgal or inorganic. Some have been interpreted to be algal in origin (e.g. Link et al., 1978) whereas others are considered to be inorganic, such as caliche (Hubert, 1977), tufa (Wheeler \& Textoris, 1978), and calcareous sinter (Riding, 1979). The presence of hemispheroids with stacked concentric laminae and detrital sand grains on the inclined sides of hemispheroids, which implies organic stabilization, suggests that the laminae in the Copper Harbor Conglomerate carbonate deposits are indeed cryptalgal.

The occurrence of these stromatolites in alluvial fan deposits also has interesting palaeoenvironmental implications. In addition, the stromatolites and associated deposits are noteworthy because of the variety of carbonate fabrics they contain, particularly radialfibrous calcite, which occurs in ooids, and stromatolitic and oncolitic coatings. Some of these fabrics are enigmatic when compared with modern carbonates 


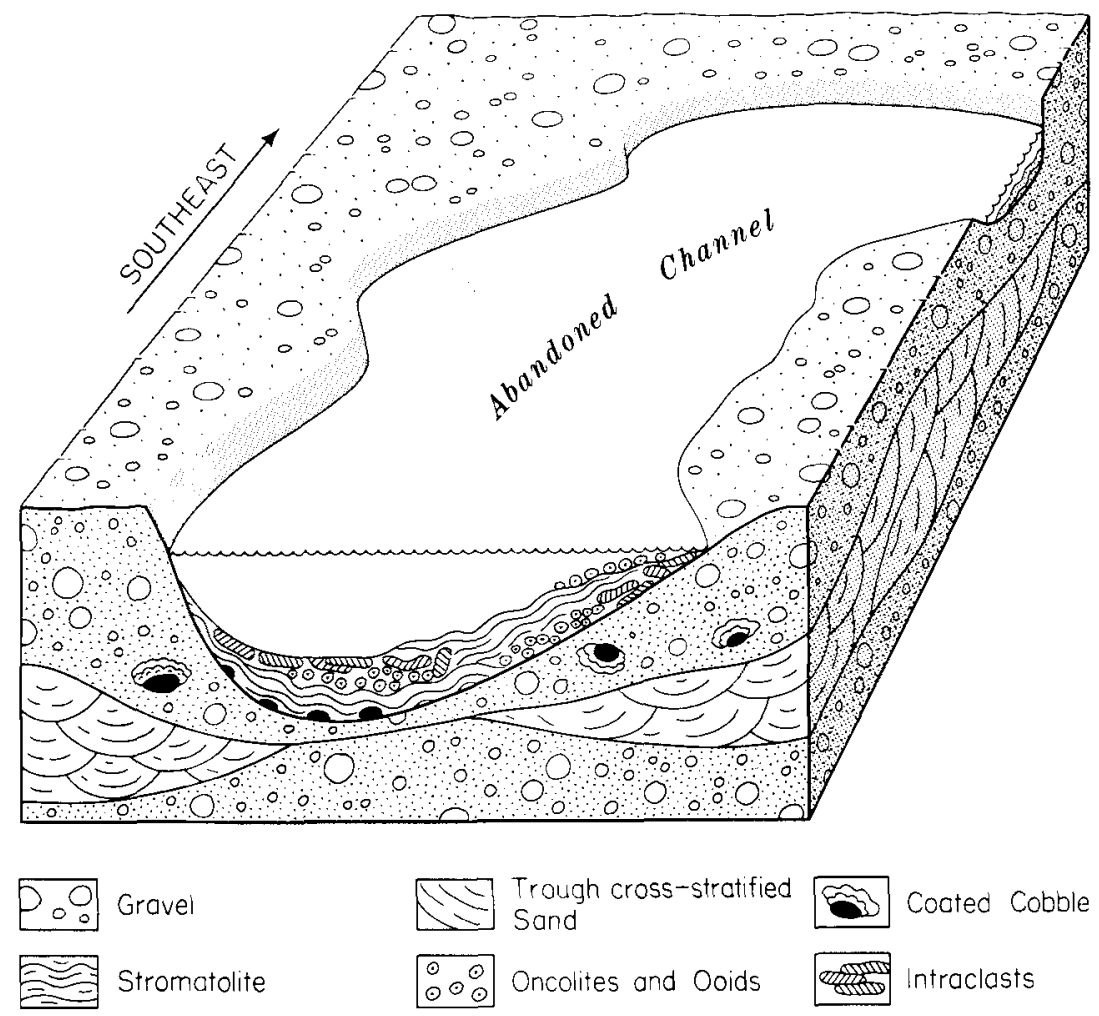

Fig. 9. Schematic reconstruction of the depositional environment in which the stromatolites and associated deposits formed.

and pose a number of interesting questions such as whether they are primary or secondary and organic or inorganic.

\section{Depositional environment}

As previously described, the facies in the Copper Harbor Conglomerate record deposition by braided stream processes. Similar modern deposits most commonly are on or associated with alluvial fans (Bull, 1972; Boothroyd \& Nummedal, 1978). Studies of these fans have documented that a spectrum of fan types exists, ranging from 'wet' fans formed by perennial braided-stream processes in humid climates, to 'dry' fans formed by ephemeral braided-stream and debris flow processes in arid climates (Schumm, 1977; Boothroyd \& Nummedal, 1978). The predominance of braided stream facies and lack of debris flow deposits in the Copper Harbor Conglomerate suggest deposition on a 'wet' type of fan (Boothroyd \& Nummedal, 1978), or some other setting dominated by braided stream deposits such as a braid plain (Rust,
1979). The abundance of features common in modern ephemeral streams might even be expected if Precambrian hydrologic regimes in humid climates were flashy as predicted by Schumm (1977). Energy conditions on the fan or braidplain were probably variable, as indicated by the association of high and low flow regime stratification types. The interbedding of such features and the general fining-upward trend in the conglomerate-mudstone facies suggest abandonment of channels.

The growth of stromatolites would require standing water in ponded areas such as abandoned channels (Fig. 9). Also, such ponds or lakes must have been of considerable size in order to provide the wave agitation necessary for ooid growth. Although the stromatolites were able to withstand the influx of overbank fines and even some coarse clastics, incorporating such detritus into the laminae, subsequent reoccupation of the ponded areas by active channels resulted in erosion of some stromatolites and deposition of coarse clastics over others.

Standing water on a braidplain or alluvial fan 
implies either an impermeable layer that locally elevated the water table, for which there is noevidence, or a high water table maintained by high precipitation in a humid climate. Although the Copper Harbor Conglomerate has similarities with the 'wet' type of fan, which would imply a humid climate, the occurrence of gypsum pseudomorphs and carbonate-filled cracks suggests an arid or semi-arid climate during deposition. The calcareous stromatolites and associated carbonate deposits also imply relatively arid conditions; similar modern deposits form in arid or semi-arid climates where evaporation is an important factor in shifting the $\mathrm{CO}_{2}-\mathrm{H}_{2} \mathrm{O}-\mathrm{CaCO}_{3}$ system toward precipitation. An arid climate precludes a high water table maintained by high precipitation and requires another mechanism for water level maintenance, such as close proximity to a lake and local elevation of the water table. This scenario is reasonable because there probably was a distal lake; the stromatolites occur in the upper part of the Copper Harbor Conglomerate, below the Nonesuch shale, which is a lacustrine deposit. The stromatolites may represent periods when the lake encroached over the distal and arid fan, thereby flooding abandoned channels and temporarily elevating the local water table. Conversely, climates may have been monsoonal, with a rainy season when the stromatolites grew and a dry season when the gypsum and other features indicating an arid climate, were formed.

\section{Carbonate fabrics}

Many ancient ooids, like those in the Copper Harbor Conglomerate, exhibit a radial fabric developed through elongation of primary carbonate crystals normal to their substrates. Some authors have suggested that a radial fabric in ancient ooids is diagenetic, having formed from an original tangential orientation (e.g. Shearman, Twyman \& Karimi, 1970). Friedman et al. (1973), however, and other authors (e.g. Kahle, 1974; Sandberg, 1975; Wilkinson \& Landing, 1978) have suggested that radial fabric in ooids is primary. Because of the lack of evidence for a diagenetic origin of the radial fabric in the Copper Harbor Conglomerate ooids, and because of their similarity to other ancient ooids, their fabric is therefore interpreted to be primary.

The radial calcite in the oncolites and stromatolites is similar to that in the ooids, and to that reported from other ancient stromatolites. Link et al. (1978) interpreted the radial calcite to be primary and algal in origin, although Horodyski (1975) suggested that such fabrics could be secondary. Riding (1979) interpreted crusts with radial fibrous calcite from lacustrine algal carbonates of Triassic age in Germany as inorganic sinter, but Wolff \& Fuchtbauer (1976) interpreted the same fabric as algal in origin. Carozzi (1964) described radial ooids and fibrous crusts of calcite in Triassic non-marine deposits and interpreted them as inorganic structures.

Wright (1981) reported pisoids with fibrous calcite laminae from lower Carboniferous deposits of South Wales, and interpreted them as having formed in a schizohaline lagoon. He noted that the fibrous calcite laminae displayed calcitization textures, and interpreted them as a replacement product of aragonite. Although the radial fibrous calcite superimposed on the laminae in the Copper Harbor Conglomerate stromatolites and oncolites is similar to the laminae described by Wright (1981), they do not contain calcitization textures that would suggest an acicular aragonitic or high magnesian calcite precursor.

Aragonite-crusted pisoids and aragonitic crusts with fabrics similar to those in the Copper Harbor Conglomerate deposits have also been reported from a number of recent hypersaline settings (Purser \& Loreau, 1973; Friedman et al., 1973; von der Borch, Bolton \& Warren, 1977; as well as others). Many workers believe that algae influenced the precipitation of the aragonite in the crusts by removing $\mathrm{CO}_{2}$. The calcite in the Copper Harbor Conglomerate stromatolites is also similar to a pseudo-radial fabric, controlled by algal filaments, observed in some modern stromatolites (Monty \& Hardie, 1976; Monty, 1976) and in oncoids (Jones \& Wilkinson, 1978). The Copper Harbor Conglomerate stromatolites and oncolites, however, do not contain algal filaments.

The radial-fibrous fabric is also similar to the pisolites and encrustations in Recent spring-fed lakes of the Bolivian Andes (Risacher \& Eugster, 1979). This calcite presumably is low-Mg calcite, and algae are not thought to have played a direct role in their formation, although they may have contributed passively by removing $\mathrm{CO}_{2}$ during photosynthesis.

It is apparent from the above discussion that determining the origin of radial-fibrous fabrics in stromatolites and similar deposits is not always straightforward. Interpretations span a spectrum from biochemical through indirectly biochemical to physiochemical. There is little direct evidence that allows accurate placement of the radial-fibrous fabrics described here into this spectrum. The similarity of the calcite to inorganically precipitated radial fibrous calcite suggests that algae need not have been directly 
involved in formation of the fabric. The association with stromatolitic and oncolitic laminae, however, suggests that algae may have indirectly initiated precipitation of carbonate.

\section{CONCLUSIONS}

(1) Facies of the Copper Harbor Conglomerate on the north-eastern part of the Keweenaw Peninsula were deposited in braided streams on the mid-fan part of an alluvial fan complex. Cobble-to-boulder conglomerate and trough cross-stratified sandstone were deposited in braided channels as longitudinal bars and migrating dunes, respectively. A complex association of lithologies ranging from conglomerate to mudstone record gradual abandonment of channels, with conglomerates deposited during re-occupation of the channels by flood water and mudstones laid down during overbank deposition.

(2) Laminated carbonates and beds with ooids, oncolites, and intraclasts are interstratified with these clastic facies. Laminated carbonates occur as contorted beds in mudstone and as laterally linked hemispheroids over cobbles. Laminae in these beds are interpreted to be algal in origin, deposited in lakes on an alluvial fan, probably abandoned channels.

(3) Although the laminae are interpreted to be algal in origin, the origin of radial-fibrous calcite superimposed on the laminae is problematic. The fabric is similar to inorganic radial-fibrous carbonate, suggesting that the carbonate need not have been precipitated by algae, but may have resulted from inorganic processes.

(4) Abundant mud drapes (which may indicate deposition by ephemeral streams), carbonate-filled syneresis or desiccation cracks, and gypsum moulds suggest deposition in an arid climate. Stromatolites, however, require standing water for growth, which seems incongruous on a permeable fan surface in an arid climate. This suggests that the abandoned channel had a locally elevated water table, possibly because it was near the Nonesuch Lake.

\section{ACKNOWLEDGMENTS}

I wish to thank Bruce Wilkinson for his advice during preparation of the manuscript. The paper benefited from critical reviews by $\mathbf{B}$. Wilkinson, B. Kelley, R.
Horodyski, J. Donaldson, B. Owen, and Rob Van der Voo. The study was supported by a Geological Society of America Penrose Grant, a Sigma Xi Grants-inAid, and an award by the Scott Turner Fund of The University of Michigan.

\section{REFERENCES}

Abel.l, P.I., AWramik, S.M., Osborne, R.H. \& Tomellini, S. (1982) Pleistocene lacustrine stromatolites from Lake Turkana, Kenya: morphology, stratigraphy and stable isotopes. Sedim. Geol. 32, 1-26.

AITKEN, J.D. (1967) Classification and environmental significance of cryptalgal limestones and dolomites, with illustrations from the Cambrian and Ordovician of southwest Alberta. J. sedim. Petrol. 37, 1163-1178.

BELT, E.S. (1966) Carboniferous continental sedimentation, Atlantic Provinces, Canada. In: Late Paleozoic and Mesozoic Continental Sedimentation, Northeastern North America (Ed. by G. de V. Klein). Spec. Pap. geol. Soc. Am. 106, 127-171.

Boothroyd, J.C. \& Ashley, G.M. (1975) Processes, bar morphology and sedimentary structures on braided outwash fans, northeastern Gulf of Alaska. In: Glaciofluvial and Glaciolacustrine Sedimentation (Ed. by A. V. Jopling and B. C. McDonald). Spec. Publs Soc. econ. Paleont. Miner., Tulsa, 23, 193-222.

BOOTHROYD, J.C.\& NUMMEDAL, D. (1978) Proglacial braided outwash: A model for humid fan deposits. In: Fluvial Sedimentology (Ed. by A. D. Miall). Mem. Can. Soc. Petrol. Geol. 5, 641-668.

BRADLEY, W.H. (1929) Algae reefs and oolites of the Green River Formation. Prof. Pap. U.S. geol. Surv. 154-C, 203223

BULL, W.B. (1972) Recognition of alluvial fan deposits in the stratigraphic record. In: Recognition of Ancient Sedimentary Environments (Ed. by W. K. Hamblin and J. K. Rigby). Spec. Publs Soc. econ. Paleont. Miner., Tulsa, 16, 63-83.

Butron, A. (1973) Algal stromatolites of the Early Proterozoic Wolkberg Group, Transvaal sequence. J. sedim. Petrol. 43, 160-167.

Carozzi, A.V. (1964) Complex ooids from Triassic Lake Deposit, Virginia. Am. J. Sci. 262, 231-241.

Clemmensen, L.B. (1978) Lacustrine facies and stromatolites from the middle Triassic of East Greenland. J. sedim Petrol. 48, 1111-1128.

Cornwall, H.R. (1954) Bedrock Geology of the Lake Medora quadrangle, Michigan. U.S. geol. Surv. Quad. Map GQ-52.

CoRnwall, H.R. (1954) Bedrock Geology of the Fort Wilkins quadrangle, Michigan. U.S. geol. Surv. Quad. Map 74

Donovan, R.N. \& Foster, R.J. (1972) Subaqueous shrinkage cracks from the Caithness Flagstone Series (Middle Devonian) of northeast Scotland. J. sedim. Petrol. 42, 309 317.

FanNin, N.G.T. (1969) Stromatolites from the Middle Old Red Sandstone of western Orkney. Geol. Mag. 106, 77-88. 
Fowler, J.H. \& KUENZI, W.D. (1978) Keweenawan turbidites in Michigan (deep borehole red beds): a foundered basin sequence developed during evolution of a protoceanic rift system. J. geophys. Res. 83, 5833-5843.

Friedman, G.M., Amiel, A.J., Braun, M. \& Miller, D.S. (1973) Generation of carbonate particles and laminites in algal mats-example from sea-marginal hypersaline pool, Gulf of Aquaba, Red Sea. Bull. Am. Ass. Petrol. Geol. 57, $541-557$

GlenNIE, K.W. (1970) Desert Sedimentary Environments. Developments in Sedimentology, 14. Elsevier, New York. $222 \mathrm{pp}$.

HAMBLIN, K.W. \& HoRnER, W.J. (1961) Sources of Keweenawan conglomerates of northern Michigan. J. Geol. 69, 204-211.

Hedlund, D.C. (1953) An algal limestone in the Keweenawan of upper Michigan. M.S. Thesis. University of Wisconsin. $45 \mathrm{pp}$.

Henry, S.G., Mauk, F.J. \& Van der Voo, R. (1977) Paleomagnetism of upper Keweenawan sediments: the Nonesuch Shale and Freda Sandstone. Can. J. Earth Sci. 14, 1128-1138.

Hofmann, H.J. (1969) Attributes of stromatolites. Pap. geol. Surv. Can. 69-39, 1-58.

Hoffman, P. (1976) Environmental diversity of Middle Precambrian stromatolites. In: Stromatolites (Ed. by M. R. Walter), pp. 599-611. Developments in Sedimentology, 20. Elsevier, Amsterdam

HoRodyski, R.J. (1975) Stromatolites of the lower Missoula Group (Middle Proterozoic), Belt Supergroup, Glacier National Park, Montana. Precambrian Res. 2, 215-254.

Hubert, J.F. (1977) Paleosoil caliche in the New Haven Arkose, Connecticut: record of semiaridity in Late Triassic-Early Jurassic time. Geology, 5, 302-304.

JONES, F.G. \& WILKINSON, B.H. (1978) Structure and growth of lacustrine pisoliths from Recent Michigan marl lakes. J. sedim. Petrol. 48, 1103-1110.

Kahle, C.F. (1974) Ooids from Great Salt Lake, as an analogue for the genesis and diagenesis of ooids in marine limestones. $J$. sedim. Petrol. 44, 30-39.

KARCZ, I. (1972) Sedimentary structures formed by flash floods in southern Israel. Sedim. Geol. 7, 161-182.

KRYLOV, I.N. (1982) Lacustrine stromatolites from the Kyzylgir Formation (Pliocene), Altai Mountains, USSR Sedim. Geol. 32, 27-38

Link, M.H., Osborn, R.H. \& Awramik, S.M. (1978) Lacustrine stromatolites and associated sediments of the Pliocene Ridge Route Formation, Ridge Basin, California J. sedim. Petrol 48, 143-158.

Miall, A.D. (1977) A review of braided-river depositional environments. Earth Sci. Rev. 13, 1-62.

Miall, A.D. (1978) Lithofacies types and vertical profile models in braided deposits: a summary. In: Fluvial Sedimentology (Ed. by A. D. Miall). Mem. Can. Soc. Petrol. Geol. 5, 597-604.

Morey, G.B. (1974) Cyclic sedimentation of the Solar Church Formation (upper Precambrian Keweenawan) southeastern Minnesota. J. sedim. Petrol. 44, 872-884.

MonTY, C.L.V. (1976) The origin and development of cryptalgal fabrics. In : Stromatolites (Ed. by M. R. Walter), pp. 193-249. Developments in Sedimentology, 20. Elsevier, Amsterdam.
Monty, C.L.V. \& HARdie, L.A. (1976). The geological significance of freshwater blue-green algal calcareous marsh. In : Stromatolites (Ed. by M. R. Walter), pp. 447477. Developments in Sedimentology, 20. Elsevier, Amsterdam.

NoRDENG, S.C. (1963) Precambrian stromatolites as indicators of polar shift. In: Polar Wandering and Continental Drift (Ed. by A. C. Munyan). Spec. Publs Soc. econ. Paleont. Miner., Tulsa, 10,131-139.

Plummer, P.S. \& Gostin, V.A. (1981) Shrinkage cracks: desiccation or synaeresis? J. sedim. Petrol. 51, 1147-1156.

PURSER, B.H. \& LOREAU, J.P. (1973) Aragonitic, supratidal encrustations on the Trucial Coast, Persian Gulf. In: The Persian Gulf(Ed. by B. H. Purser), pp. 343-376. SpringerVerlag, New York.

RIDING, R. (1979) Origin and diagenesis of lacustrine algal bioherms at the margin of the Ries Crater, Upper Miocene, southern Germany. Sedimentology, 26, 253-270.

RisaCHER, F. \& EUGSTER, H.P. (1979) Holocene pisoliths and encrustations associated with spring-fed surface pools, Pastos Grandes, Bolivia. Sedimentology, 26, 253-270.

Rust, B.R. (1979) Coarse alluvial deposits. In : Facies Models (Ed. by R. G. Walker), pp. 9-22. Geosciences in Canada Series 1. Geological Society of Canada.

SANDBERG, P.A. (1975) New interpretations of Great Salt Lake ooids and of ancient nonskeletal carbonate mineralogy. Sedimentology, 22, 497-537.

SchumM, S.A. (1977) The Fluvial System. Wiley (Interscience), New York. $335 \mathrm{pp}$.

Shearman, D.J., Twyman, J. \& Karimi, M.Z. (1970) The genesis and diagenesis of oolites. Proc. geol. Ass. 81, 561575

SURDAM, R.C. \& WRAY, J.L. (1976) Lacustrine stromatolites, Eocene Green River Formation, Wyoming. In : Stromato lites (Ed. by M. R. Walter), pp. 535-541. Developments in Sedimentology, 20. Elsevier, Amsterdam.

VON DER BORCH, C.C., BOLTON, B. \& WARREN, J.K. (1977) Environmental setting and microstructure of subfossil lithified stromatolites associated with evaporites, Marion Lake, South Australia. Sedimentology, 24, 693-708

WALKER, R.G. (1975) Conglomerate: sedimentary structures and facies models. In: Depositional Environments as Interpreted from Primary Sedimentary Structures and Stratification Sequences (Ed. by J. C. Harms, D. R. Southward, and R. G. Walker). Soc econ. Paleont. Mineral., Dallas Short Course, 133-161.

Wheeler, W.H. \& Textoris, D.A. (1978) Triassic limestone and chert of playa origin in North Carolina. J sedim. Petrol. 48, 765-776.

White, W.S. (1960) The Keweenawan lavas of Lake Superior, an example of flood basalts. Am. J. Sci. 258A, 367-374.

WHITE, W.S. (1968) The native-copper deposits of northern Michigan. In: Ore Deposits of the United States, 1933-1967 (Ed. by J. D. Ridge), pp. 303-325. American Institute of Mining, Metallurgy, and Petroleum Engineering, New York.

WhITE, W.S. \& WRIGHT, J.C. (1960) Lithofacies of the Copper Harbor Conglomerate, northern Michigan. Prof. Pap. U.S. geol. Surv. 400-B, B5-B8.

Wilkinson, B.H. \& LANDing, E. (1978) "Eggshell diagenesis" and primary radial fabric in calcite ooids. $J$. sedim. Petrol. 48, $1129-1138$. 
WOLFF, M. \& FUChTBaUER, H. (1976) Die karbonatische Randfazies der tertiaren Susswasserseen des Nordlinger Ries und des Steinheimer Beckens. Geol. $J b$. 14, 3-53.
WRIGHT, V.P. (1981) Algal aragonite-encrusted pisoids from a lower Carboniferous schizohaline lagoon. J. sedim. Petrol. 51, 479-489.

(Manuscript received 9 September 1982; revision received 16 April 1983) 